Science of the Total Environment, Volume 690, 10 November 2019, pp. 730-738

DOI:10.1016/j.scitotenv.2019.06.360

\title{
Decision framework for the environmental management of explosive contaminated land
}

\author{
M.K. Ladyman*a, T.J. Temple ${ }^{\mathrm{a}}$, M.M. Piperakis ${ }^{\mathrm{a}}$, W. Fawcett-Hirst ${ }^{\mathrm{a}}$, E. Gutierrez-Carazo ${ }^{\mathrm{a}}$, F. \\ Coulon $^{\mathrm{b}}$
}

${ }^{\text {a }}$ Cranfield University, Centre for Defence Chemistry, Defence Academy of the United Kingdom, Shrivenham, SN6 7LA, UK

${ }^{\mathrm{b}}$ Cranfield University, School of Water, Energy and Environment, Cranfield, MK43 0AL, UK *Corresponding author: m.ladyman@,cranfield.ac.uk Cranfield University, Centre for Defence Chemistry, Defence Academy of the United Kingdom, Shrivenham, SN6 7LA, UK

\begin{abstract}
The environmental risks from explosive manufacturing and testing activities are usually evaluated using a qualitative process such as environmental impact prioritisation as recommended by legislation and guidance. However, standard environmental management system (EMS) guidance rarely provides detailed information on how to objectively assess the significance of the environmental impacts based on a rational scientific evidence. Quantitative exposure and ecotoxicity assessments are frequently used in combination with environmental threshold limit guidelines, but these omit important environmental impacts such as physical damage to land, nuisance and contribution to climate change. These impacts are particularly relevant to the explosives industry where noise nuisance and physical damage are given high priority. In addition, contamination from explosive compositions may comprise mixtures of multiple legacy and new generation explosives such as 1,3,5-trinitro-1,3,5-triazinane (RDX), 2,4,6-trinitrotoluene (TNT), 5nitro-1,2,4-triazol-3-one (NTO), 2,4-dinitroanisole (DNAN) and nitroguandine (NQ), which may have combinedcombined impacts not captured by conventional eco-toxicity assessments. Further, threshold limits for energetic materials in soil and water have not been established for most nations. Additionally, in the explosive industry wider concerns such as legislative compliance and stakeholder concerns may help to provide a more broadly applicable assessment of environmental impact. Therefore in this study a novel decision framework was developed to integrate empirical
\end{abstract}


data with business risks to enable rational decision making for the environmental management of explosive manufacturing facilities. The application of the framework was illustrated using three case studies from the explosive manufacturing industry to demonstrate how the framework can be used to justify environmental management decision making. By linking the environmental impacts to business risks, we demonstrate that manufacturers are able to assess a wide spectrum of issues that might not be identified in the initial environmental assessment such as non-toxic pollution incidents, breaches in legislation and stakeholder perceptions.

Keywords: Environmental impact assessment, business risk, soil contamination, water contamination, air pollution

\subsection{Introduction}

Due to the importance of personal safety when handling explosives and energetic materials, environmental considerations have historically been marginalised at all stages of the lifecycle from design to disposal (1). However, with increasingly stringent legislative requirements and burgeoning public awareness it is essential to manage the environmental impact of explosives. Both the manufacturers and users of explosives are responsible for any adverse impacts on the environment from explosives by legislation such as the Contaminated Land (England) Regulations 2006 (2), Water Resources Act 1991 (3) and the Environmental Permitting Regulations 2010 (4). Therefore, environmental management systems such as ISO14001 and other environmental assessment tools such as lifecycle analysis (ISO140040) have become a ubiquitous way for organisations to ensure compliance with environmental legislation, and mitigate or minimise their environmental impact through life (5-7). This is equally true for private business and government organisations, where bespoke management systems have been developed ( 8 ).

Adverse impact on the environment from explosive manufacturing and training activities is usually determined by a qualitative process such as environmental impact prioritisation, in which a matrix is used to prioritise significant impacts based on the likelihood and severity (7-9). The aim of the prioritisation is to indicate the likely significant environmental impacts of an organisation's activities, 
and highlight where mitigation of adverse impacts is required (10). However, there is no standardised method for prioritisation and organisations may adopt their own approaches, which causes inconsistency in how impact is prioritised (11). An additional complication when assessing the significance of environmental impact is where there are uncertainties e.g. where the severity of impact on specific environmental receptors is unknown (12). The qualitative process should highlight areas where further quantitative assessment is required in order to effectively assess the severity of the impact. Adverse impact on the environment from explosive manufacturing and training activities is usually determined by a qualitative process such as environmental impact prioritisation, in which a matrix is used to prioritise significant impacts based on the likelihood and severity (9-11). The aim of the prioritisation is to indicate the likely significant environmental impacts of an organisation's activities, and highlight where mitigation of adverse impacts is required (12). However, there is no standardised method for prioritisation and organisations may adopt their own approaches, which causes inconsistency in how impact is prioritised (13). An additional complication when assessing the significance of environmental impact is where there are uncertainties e.g. where the severity of impact on specific environmental receptors is unknown (14). The qualitative process should highlight areas where further quantitative assessment is required in order to effectively assess the severity of the impact.

Current quantitative environmental assessment methodologies often quantify severity using exposure assessment, which is based on the likely concentrations of a contaminant in the environment, compared to guideline exposure limits developed from eco-toxicology (15). However, exposure limits are often only established for single pollutants, which is not truly representative of an organisation's activities. For example, explosive manufacturing wastewater and soil contaminated with energetic materials may contain mixtures of multiple legacy and new-generation explosives such as 1,3,5-trinitro-1,3,5-triazinane (RDX), 2,4,6-trinitrotoluene (TNT), 5-nitro-1,2,4-triazol-3-one (NTO), 2,4-dinitroanisole (DNAN) and nitroguandine (NQ), which may have combined impacts not captured by threshold limits (16-22). Although the eco-toxicology of energetic materials has been 
studied (23-26), globally few countries have established threshold limits for energetics in soil and water. The United States Environmental Protection Agency (US EPA) has established guideline exposure limits for the most common energetic contaminants and their degradation products, and these limits are frequently applied by other nations $(27,28)$. The efficiency of impact assessment for explosives is therefore limited as empirical data is often incomplete or unavailable, and standard environmental management systems are not prescriptive in how to evidence and obtain this information $(13,29)$.

A further limitation of the exposure assessment approach is that it does not encapsulate all types of adverse environmental impact regulated by legislation (30). For example, nuisance legislated in the UK under the Environmental Protection Act 1990 (31), is also considered an environmental impact. This is particularly relevant during the in-service and disposal phases of a munition's lifecycle, e.g. noise nuisance from training and odour and black smoke from open-burning for disposal (32). In addition, exposure and ecotoxicology assessment cannot assess damage to eco-systems comprising a complex network of multiple species, or physical damage to the landscape, e.g. from detonations, and therefore may not be able to provide a holistic assessment of impact severity as defined by legislation and stakeholder requirements.

The prioritisation or assessment of environmental impact is frequently carried out using a value judgement approach, which is highly subjective according to the beliefs and judgements of those carrying out the assessment (31). Efforts have been made to develop less subjective assessment methods. For example, the European Commission recommendation for the Environmental Management Assessment Scheme (EMAS) suggests one way to assess impact is to use 'yes' and 'no' questions, rather than a sliding scale, such as whether an activity has the potential to cause harm to the environment (32). Where uncertainties exist the most efficient way to introduce objectivity is to evidence decisions using empirical data based on scientific rationale $(33,34)$. The use of exposure limits and eco-toxicity reduces the effectiveness of environmental assessment where such data are unavailable, this can be mitigated by including a wider definition of impact. For example, ISO 14004 
on general guidelines for environmental management systems recommends the inclusion of wider concerns such as legislative, political, financial and stakeholder concerns which can be assessed on factual information such as whether legislative requirements have been met or whether penalties will be incurred (35). This approach is also recommended by the European Commission guidance for EMAS (32), and has been applied to the healthcare industry (36), local authorities (37) and water companies (38). The inclusion of wider concerns enables organisations to link environmental impacts with business risk, which may help to demonstrate the importance of environmental management to both internal employees and stakeholders (39). The prioritisation or assessment of environmental impact is frequently carried out using a value judgement approach, which is highly subjective according to the beliefs and judgements of those carrying out the assessment (33). Efforts have been made to develop less subjective assessment methods. For example, the European Commission recommendation for the Environmental Management Assessment Scheme (EMAS) suggests one way to assess impact is to use 'yes' and 'no' questions, rather than a sliding scale, such as whether an activity has the potential to cause harm to the environment (34). Where uncertainties exist the most efficient way to introduce objectivity is to evidence decisions using empirical data based on rational scientific principles $(35,36)$. The use of exposure limits and eco-toxicity reduces the effectiveness of environmental assessment where such data are unavailable, this can be mitigated by including a wider definition of impact. For example, ISO 14004 on general guidelines for environmental management systems recommends the inclusion of wider concerns such as legislative, political, financial and stakeholder concerns which can be assessed on factual information such as whether legislative requirements have been met or whether penalties will be incurred (37). This approach is also recommended by the European Commission guidance for EMAS (34), and has been applied to the healthcare industry (38), local authorities (39) and water companies (40). The inclusion of wider concerns enables organisations to link environmental impacts with business risk, which may help to demonstrate the importance of environmental management to both internal employees and stakeholders (41). 
It is clear that while EMS provide organisations a mechanism to manage their environmental impact, there are challenges to undertaking an objective evidence-based impact assessment that incorporates all types of adverse environmental impacts and their consequences to the business. To address this we developed a novel Decision Frameworkthat integrates empirical data with business risks to enable decision making for the environmental management of explosive manufacturing facilities. This paper demonstrates the application of the framework in three real case studies from the explosivemanufacturing industry, and shows how the framework can be used to justify and evidence environmental management decisions.

\subsection{Development of the Decision Framework for environmental management of explosives}

The Decision Framework was initially designed to complement a manufacturers' existing environmental assessment strategy by incorporating broader business risks that may affect operational output, and to provide evidence of transparent and objective decision making in environmental management. The Decision Framework achieves this by encouraging organisations to ask and obtain answers to directed questions about the extent and severity of a potential environmental impact arising from an operational process to determine if there is an unacceptable risk to the business (Figure 1) (42). The questions should indicate the level of scientific investigation required into a particular environmental impact, which may include analysis of physical soil, air and water samples, toxicity assays, prediction modelling or literature searching. Results from these investigations enable the organisation to determine the extent and severity of the environmental impact and can then be used to make a simple binary decision on whether the activity can continue unchanged or if mitigation is required. This approach allows the incorporation of environmental best practice into operational activities through the scientific analysis of risks. 


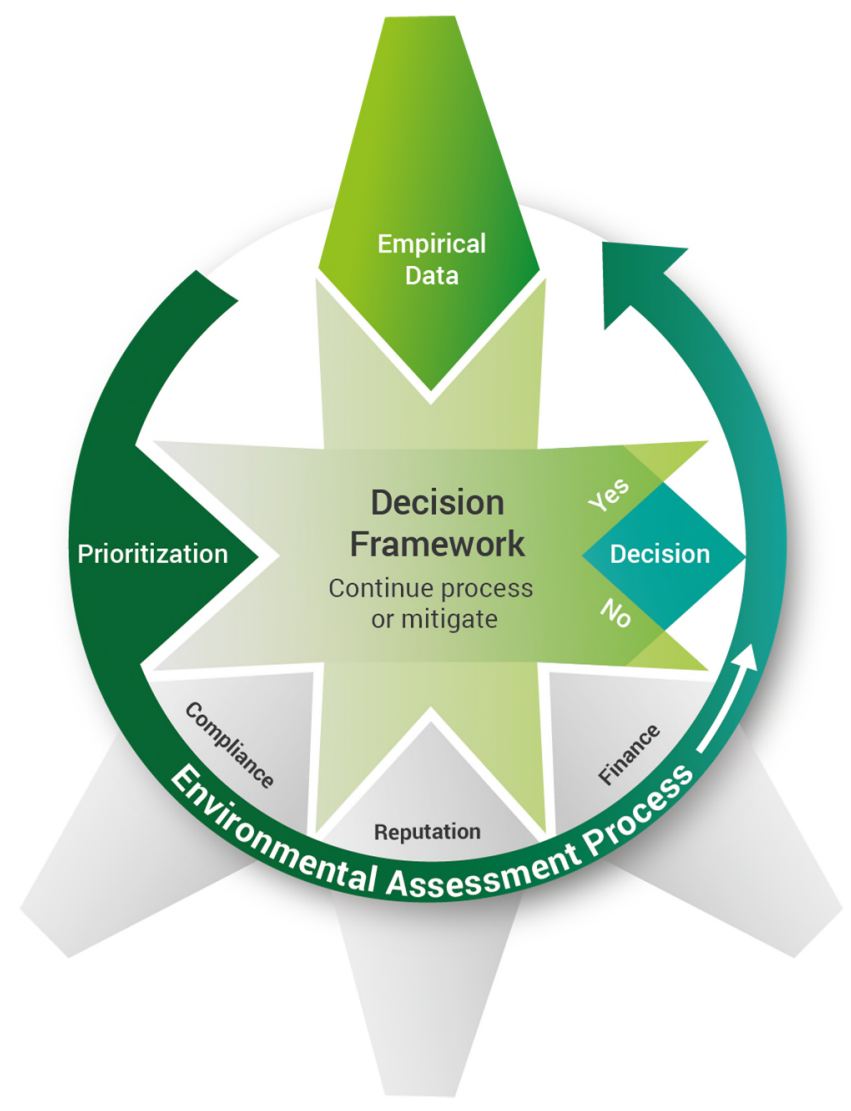

Figure 1: The Decision Framework is integrated with an organisation's Environmental Assessment process by incorporating relevant business risks (compliance, reputation and finance) to capture wider environmental management opportunities. The Decision Framework ensures that decisions are evidenced by technical and scientific data.

The Decision Framework (Figure 2) is a concise matrix comprising of four consecutive stages that focus on how potential environmental impacts identified in an organisation's environmental assessment process can lead to business risks. The concept of 'business risk' for the Decision Framework was developed using the principles of sustainability, which aim to balance environmental, social and economic factors (43). As the Decision Framework was developed for use in the explosive manufacturing industry the terminology for the risk categories was chosen to represent the key areas of concern therefore compliance, reputation and finance were selected in addition to the environmental impacts drawn-down from the manufacturer's environmental assessment. These are representative of social (reputation, compliance), economic (financial) and environmental (compliance). Compliance was selected because it is mandatory for all industry and government organisations to comply with legislation. Reputational concerns were also highlighted as the use and manufacture of explosives is under intense scrutiny from the public due to the ethical and political 
implications. Finally, financial risks were included as adverse environmental impacts can incur financial penalties reflecting legislative non-compliance, remediation and compensation, which may need to be considered within the organisational budget.

The Decision Framework begins with drawdown of potentially high environmental impacts from the organisation's EIA that are then expanded to include broader risks to compliance, reputation and finance (Stage 1). The Decision Framework should be used where there is significant uncertainty regarding the environmental impact of a particular process that requires objective assessment. In Stage 2, clear directed questions are developed to evidence the requirement for appropriate scientific analysis. Results from the scientific studies can then be summarised to make a 'yes' or 'no' decision on whether the activity can proceed in the current way. If the organisation reviews the data and decides that there will not be a significant environmental impact, with little risk to business, the process can continue or proceed. This decision is recorded in Stage 3 of the Decision Framework, and colour coded 'green'. Conversely, if the organisation decides that the environmental impact is significant, and the risk is too high to allow the process to continue or proceed, the decision is colour coded 'red' in the Decision Framework. The final step (Stage 4) is to record potential mitigation solutions, which may be immediately applicable, or may require further investigation to demonstrate feasibility. This mitigation process can also be supported by the Decision Framework, and the solution embedded into the EMS review process.

Table 1: The Decision Framework is supported by a template that documents and outlines the summary of results or conclusions from each stage. Guidance is embedded in the template describing what should be included. The template is intended to become a summary document with clear links to all supporting information that evidences the decisions made.

\begin{tabular}{|c|c|c|c|c|c|}
\hline \multirow{2}{*}{\multicolumn{2}{|c|}{ Stage }} & \multirow{2}{*}{$\begin{array}{l}\text { Potential } \\
\text { Environmental Impact }\end{array}$} & \multicolumn{3}{|c|}{ Business Risks } \\
\hline & & & Compliance & Reputation & Finance \\
\hline 1 & $\begin{array}{l}\text { Operational } \\
\text { risks arising } \\
\text { from potential } \\
\text { adverse } \\
\text { environmental } \\
\text { impact }\end{array}$ & $\begin{array}{l}\text { Describe potentially } \\
\text { significant environmental } \\
\text { impacts arising from } \\
\text { activity as identified in } \\
\text { environmental } \\
\text { assessment (Link to } \\
\text { external documents). }\end{array}$ & \multicolumn{3}{|c|}{$\begin{array}{l}\text { Describe resulting compliancy, reputation and financial risks } \\
\text { from the identified environmental impacts. }\end{array}$} \\
\hline \multirow[t]{2}{*}{2} & $\begin{array}{l}\text { Questions } \\
\text { arising from } \\
\text { risk assessment. }\end{array}$ & $\begin{array}{l}\text { State questions that must } \\
\text { be answered to evaluate } \\
\text { the severity, frequency or } \\
\text { extent of the impact. }\end{array}$ & \multicolumn{3}{|c|}{$\begin{array}{l}\text { State questions that must be answered to determine level of } \\
\text { risk to operations. Link to associated documents e.g. } \\
\text { proposed and ongoing programs of work. }\end{array}$} \\
\hline & \multicolumn{2}{|c|}{ Scientific investigations undertaken. } & & & \\
\hline \multirow[b]{2}{*}{3} & & \multirow[b]{2}{*}{$\begin{array}{l}\text { Summarise results from } \\
\text { scientific investigations } \\
\text { and link to original } \\
\text { documents. }\end{array}$} & $\mathrm{Y} / \mathrm{N}$ & $\mathrm{Y} / \mathrm{N}$ & $\mathrm{Y} / \mathrm{N}$ \\
\hline & $\begin{array}{l}\text { Decision based } \\
\text { on Results }\end{array}$ & & \multicolumn{3}{|c|}{$\begin{array}{l}\text { Summarise results relevant to the risks identified in stage } 1 \\
\text { and assign a risk level. Red if results indicate that the risk is } \\
\text { unacceptable and activities should not proceed without } \\
\text { further mitigation. Green if results indicate that the risk is } \\
\text { low and activities can proceed with no further mitigation. }\end{array}$} \\
\hline
\end{tabular}




\begin{tabular}{|l|l|l|}
\hline 4 & $\begin{array}{l}\text { Mitigation } \\
\text { Option 1 }\end{array}$ & $\begin{array}{l}\text { Suggest mitigation to minimise impact. Green indicates that mitigation can proceed } \\
\text { immediately with no further action, based on risk assessment. Red indicates that further } \\
\text { investigation is required before mitigation is implemented. May link to relevant } \\
\text { documentation e.g. proposals for further work, operational controls etc... }\end{array}$ \\
\hline
\end{tabular}

\subsection{Application of the framework to explosive manufacturing facilities}

The following three case studies have been extracted from work undertaken at three different explosive manufacturing facilities to determine the severity of environmental impacts associated with operational activities and to facilitate decision making.

In the first case study, an explosive manufacturer intended to make a change to their manufacturing process and was uncertain of the extent and severity of the potential land and water contamination resulting from the change. The Decision Framework was used to support the decision to not continue with the change until mitigation was applied. The second example shows how the Decision Framework enabled an explosive manufacturer to decide whether to remediate land potentially contaminated with explosives according to legislative threshold limits. The final example demonstrates the use of the Decision Framework to integrate perception issues surrounding openburning with the severity of environmental impact and demonstrate consideration of stakeholder concerns.

\subsection{Case Study 1: Change in composition of explosive contaminated wastewater}

The first example has been extracted from real work undertaken for an explosive processing facility planning to introduce a new explosive to their portfolio. This particular processing facility had used a biological wastewater treatment system for many years to treat their explosive contaminated wastewater. From the initial desk-based environmental risk assessment conducted by the manufacturer using a severity versus frequency approach it was unknown whether using the existing system to treat wastewater from processing the new explosive would be a risk to the environment, particularly as treated water is discharged to a local river. An added concern was that the new explosive might be significantly toxic to the micro-organisms in the treatment system and harm the population. 
The environmental impact assessment conducted by the manufacturer was reviewed and the most significant risk was identified as a failure of the wastewater treatment system resulting in untreated explosive contaminated water being discharged to the environment. The consequences of this would be local water contamination and potential toxicity to flora and fauna. The Decision Framework was applied to determine resulting risks to operational capacity from non-compliance, stakeholder perception and financial penalties, as detailed in the 'risks to process' row of Figure 3. In this case, the main risk identified in the compliance column of the Decision Framework was a potential to breach the Environmental Permitting Regulations (EPR) (4), which require all facilities that discharge effluent to have a permit specific to the emitted compounds. In addition, a discharge threshold would have to be agreed with local authorities. The main risk associated with stakeholder perception was the colour of the new explosive, which had the potential to cause discolouration of discharged water. This issue could lead to loss of business due to damage to reputation, whether or not any actual contamination was caused. Both of these issues would have financial repercussions such as penalty fines and potential remediation costs, as well as implicit risks to business such as delays in production. The identified risks highlighted the need to conduct scientific research allowing a rational decision on whether to treat wastewater from the new explosive using the existing treatment facility (Figure 2). 
1 Table 2: Example of a completed Decision Framework for Case Study 1. The outcome of the application of the Decision Framework enabled the manufacturer to decide not 2 to treat manufacturing wastewater from the new explosive using the current system without undertaking further work and introducing appropriate mitigation.

\section{Potentially high impact process: Introduction of a new explosive composition requiring treatment by exisiting biological wastewater system}

\begin{tabular}{|c|c|c|c|c|c|}
\hline \multirow{2}{*}{\multicolumn{2}{|c|}{ Stage }} & \multirow{3}{*}{$\begin{array}{l}\text { Potential Environmental Impact } \\
\text { Toxicity to micro-organisms in } \\
\text { wastewater treatment plant. Potential } \\
\text { release of explosive contaminated } \\
\text { water to environment leading to } \\
\text { land/water contamination and wider } \\
\text { toxicity to flora and fauna. }\end{array}$} & \multicolumn{3}{|c|}{ Business Risks } \\
\hline & & & \multirow[b]{2}{*}{\begin{tabular}{|l|} 
Compliance \\
\\
Potential requirement for licence to \\
discharge wastewater with thresholds \\
for new explosive composition. Delays \\
to contracts due to non-compliance \\
leading to loss of business.
\end{tabular}} & \multirow{2}{*}{\begin{tabular}{|l|} 
Reputation \\
Negative public perception from \\
discolouration of water, and potential \\
toxicity effects leading to negative \\
publicity and potential loss of \\
business.
\end{tabular}} & \multirow[b]{2}{*}{\begin{tabular}{|l} 
Finance \\
Potential fines for non-compliance anc \\
pollution incidents. Costs of \\
remedation of contaminated land and \\
water. Costs from delays in \\
processing due to prohibition notices \\
and customer disatisfaction.
\end{tabular}} \\
\hline 1 & $\begin{array}{l}\text { Operational risks arising from } \\
\text { potential adverse environmental } \\
\text { impact }\end{array}$ & & & & \\
\hline 2 & $\begin{array}{l}\text { Questions arising from operational } \\
\text { risk assessment }\end{array}$ & $\begin{array}{l}\text { Is the explosive composition toxic to } \\
\text { micro-organisms at operational } \\
\text { concentrations and volumes? Does } \\
\text { the explosive cause significant } \\
\text { discolouration of discharge at } \\
\text { operational concentrations? }\end{array}$ & $\begin{array}{l}\text { What is the threshold discharge limit } \\
\text { for the new explosive composition? }\end{array}$ & $\begin{array}{l}\text { Is the explosive toxic at potential } \\
\text { discharge concentrations? What } \\
\text { concentration casues discolouration? }\end{array}$ & $\begin{array}{l}\text { How likely is non-compliance at } \\
\text { operational concentrations? How } \\
\text { likely is it that remediation would be } \\
\text { required at operational } \\
\text { concentrations? }\end{array}$ \\
\hline
\end{tabular}

Scientific investigation undertaken: Toxicity of new composition to micro-organisms, estimation of exposure concentrations, $\mathrm{pH}$ and discolouration of water at different concentrations.

\begin{tabular}{|c|c|c|c|c|c|}
\hline & Continue process? & & $\mathbf{N}$ & $\mathbf{N}$ & $\mathbf{N}$ \\
\hline 3 & Decision based on results & $\begin{array}{l}\text { Strong yellow colour in water at } \\
\text { operational concentrations. } \\
\text { Decreased pH of discharged water. } \\
\text { Cumulative toxicity impacts from the } \\
\text { three explosives are very likely to } \\
\text { occur. Toxic to microbial population. }\end{array}$ & $\begin{array}{l}\text { Threshold of explosive set at limit of } \\
\text { detection, however at operational } \\
\text { concentrations this is very likely to be } \\
\text { exceeded. Likely to receive notices } \\
\text { from local authorities requiring } \\
\text { remdiation of local waterways. }\end{array}$ & $\begin{array}{l}\text { Public perception issues when } \\
\text { discharging water due to yellow } \\
\text { discolouration from explosive could } \\
\text { lead to complaints. }\end{array}$ & $\begin{array}{l}\text { Fines or remediation costs. } \\
\text { Irreversible toxicity to bacteria in } \\
\text { treatment system could shut-down on } \\
\text { site wastewater treatment and require } \\
\text { storage or off-site treatment. } \\
\text { Increased water acidity increases } \\
\text { wear on infrastructure leading to } \\
\text { increased maitenance costs. }\end{array}$ \\
\hline 4 & Mititgation measures & $\begin{array}{l}\text { Investigate pre-treatment options for } \\
\text { wastewater, or disposal off-site. }\end{array}$ & $\begin{array}{l}\text { Discussions with local authorities to } \\
\text { agree discharge threshold limit. }\end{array}$ & $\begin{array}{l}\text { Investigate pre-treatment options to } \\
\text { remove yellow colour. }\end{array}$ & $\begin{array}{l}\text { Investigate options to neutralise water } \\
\text { before transport through wasetwater } \\
\text { infrastructure to reduce maintenance } \\
\text { costs. }\end{array}$ \\
\hline
\end{tabular}


4 The main questions developed in Stage 2 of the Decision Framework arising from the

5 environmental impacts and business risks were associated with the toxicity of the proposed

6 new explosive toward the micro-organisms in the wastewater treatment system, and the

7 severity of pollution should the wastewater treatment system fail (Figure 3). Other questions

8 generated from this stage regarded maximum discharge concentrations, and the minimum

9 concentration that would cause discolouration (Figure 3). Therefore, the manufacturer

10 commissioned laboratory experiments to assess the sensitivity of the micro-organisms toward

11 the explosive at three representative concentrations, and the colour intensity at varying

12 concentrations. The viability data were combined with the average influent volume to

13 determine predicted environmental concentrations and to determine if these would be

14 detrimental to the micro-organisms.

15 The empirical data proved that at maximum likely concentrations the new explosive was toxic

16 to the micro-organisms in the wastewater treatment plant. This data was also used to show that,

17 without implementing additional controls, there could be low concentrations of the new

18 explosive in the water discharged to the local environment, which would require a permit and

19 agreement of threshold limits. In addition, the concentration discharged to the environment

20 could be high enough to cause discolouration of water at maximum processing volumes.

21 In Stage 3, the manufacturer made a decision whether to use the existing wastewater treatment

22 facility without first implementing additional controls based on the results of the directed questions from Stage 2. The empirical data proved that the change in process could result in a significant environmental impact, and therefore the manufacturer made a 'no' decision. The results of the investigation also identified that the risk to compliance, reputation and finance

26 was high, and therefore the manufacturer also assigned a 'no' decision in these columns.

27 Overall, the manufacturer could use the Decision Framework to support and record their 
decision that use of the wastewater treatment system to treat wastewater containing the new explosive was an unacceptable risk and could not continue without mitigation (Figure 2).

If the Decision Framework had not been used to complement the initial environmental impact assessment, some elements of the scientific analysis may not have been conducted. For example, the assessment of the degree of discolouration of wastewater compared to explosive concentration would not have been conducted as this issue was raised in the reputational risk column. Without the Decision Framework, it is possible that only an eco-toxicology assessment would have been conducted, which would not have assisted with the determination of potential threshold limits as required by legislation. The Decision Framework therefore enabled the manufacturer to assess a wide spectrum of issues in addition to those identified in the initial environmental impact assessment.

\subsection{Case Study 2: Environmental impact of explosive contaminated land from open-}

\section{0 burning}

41 Open burning is industry standard for disposal of explosives and explosive contaminated waste such as personal protective equipment and cleaning materials as it is cost-effective and reduces the likelihood of accidents during transport or treatment (44). At explosive manufacturing facilities open-burning is common practice, although the environmental impact is poorly understood particularly with respect to explosives residues deposited on nearby land $(32,45)$. In the example, the manufacturer's environmental risk assessment identified contamination of nearby land and water from open-burning at the manufacturing facility as a significant potential environmental impact (Table 4). The manufacturer therefore required assurance that the openburning process was not causing off-site soil and water contamination, or a breach in

50 legislation. The Decision Framework was used to assist the manufacturer decide whether the 51 risk from contamination of land and water from open-burning was severe enough to require remediation. 
53 In stage 1 of the Decision Framework, the main risk to operational capacity was found to be 54 negative public perception should off-site contamination be detected. This would lead to costly 55 remediation and potentially a prohibition notice to cease open-burning until the source of 56 contamination was identified and mitigated. This could cause significant disruption to the 57 business, as explosive waste would need to be stored on site with limitations on quantities that 58 could potentially restrict production while waiting for off-site disposal. In stage 2 of the 59 Decision Framework the main question generated was whether open-burning was actually 60 causing a significant risk either on or off-site, which would require remediation.

61 Soil sampling in and around the open-burning area was conducted to determine whether any 62 contamination had occurred. The soil sampling methodology was based on scientifically 63 proven approaches such as multi-increment sampling that is designed to provide high 64 confidence results (46). Laboratory analysis was conducted using proven techniques such as 65 the EPA8330B extraction method, and robust soil preparation methods $(47,48)$. Results 66 showed that the land immediately adjacent to the open-burning area on-site contained very low

67 levels of explosive contamination $(>1 \mathrm{mg} / \mathrm{kg})$. Explosive residue was not detected in any of 68 the off-site soil samples, suggesting that land contamination is restricted to a localised area and 69 does not affect local environmental receptors. 
70 Table 3: Completed Decision Framework for Case Study 2. The outcome of the application of the Decision Framework highlighted a clear need for further assessment.

71 Therefore, the manufacturer decided to undertake a full assessment of the site by comprehensive soil analysis to determine that the risk to the surrounding environment was

low, and therefore operation could continue. This also prompted the manufacturer to implement a continual monitoring regime in the future.

\section{Potentially high impact process: Open-burning of explosive waste and contaminated waste}

\begin{tabular}{|c|c|c|c|c|c|}
\hline \multirow{2}{*}{\multicolumn{2}{|c|}{ Stage }} & \multirow{2}{*}{$\begin{array}{l}\text { Potential Environmnetal } \\
\text { Impacts }\end{array}$} & \multicolumn{3}{|c|}{ Business Risks } \\
\hline & & & Compliance & Reputation & Finance \\
\hline 1 & $\begin{array}{l}\text { Operational risks arising from } \\
\text { potential adverse } \\
\text { environmental impact }\end{array}$ & $\begin{array}{l}\text { Land contamination from } \\
\text { explosive residue on site. Land } \\
\text { and water contamination from } \\
\text { transport of explosive resude off- } \\
\text { site. Potential adverse effects to } \\
\text { environmental receptors. }\end{array}$ & $\begin{array}{l}\text { Potential for non-compliance with } \\
\text { threshold exposure limits in soil, } \\
\text { and in run-off from site. Potential } \\
\text { prohobition notice on open- } \\
\text { burning may cause back-loading } \\
\text { of waste. If on-site storage limits } \\
\text { are reached, expensive off-site } \\
\text { dispoal may be required or halt of } \\
\text { processing until backlog is } \\
\text { cleared. }\end{array}$ & $\begin{array}{l}\text { Negative public perception from } \\
\text { local residents due to adverse } \\
\text { environmental imacts. Potential } \\
\text { notification of authories leading to } \\
\text { prohibiton notices and } \\
\text { requirement for storage or off-site } \\
\text { disposal of waste. Loss of } \\
\text { business through negative } \\
\text { perception. }\end{array}$ & $\begin{array}{l}\text { Potential fines for non-compliance } \\
\text { and pollution incidents. Costs of } \\
\text { remedation of contaminated land } \\
\text { and water. Increased costs from } \\
\text { off-site disposal of explosive } \\
\text { contaminated waste. }\end{array}$ \\
\hline 2 & $\begin{array}{l}\text { Questions arising from risk } \\
\text { assessment }\end{array}$ & $\begin{array}{l}\text { Is there land contamination? Is } \\
\text { any contamination transported off- } \\
\text { site. }\end{array}$ & $\begin{array}{l}\text { Are there any explosive } \\
\text { thresholds for soil and water? }\end{array}$ & $\begin{array}{l}\text { Could there be any adverse } \\
\text { impacts at the relevant } \\
\text { concentrations? }\end{array}$ & Is remediation required? \\
\hline \multicolumn{6}{|c|}{ Scientific investigation undertaken: Analysis of concentration of explosive in soil in and around burning area, and soil columns. } \\
\hline \multirow[b]{2}{*}{3} & Continue process? & \multirow[b]{2}{*}{$\begin{array}{l}\text { Low levels of contamination found } \\
\text { on-site, no detection of explosive } \\
\text { contamination off site. Explosive } \\
\text { contamination remains at soil } \\
\text { surface, and does not degrade. }\end{array}$} & $Y$ & $Y$ & $Y$ \\
\hline & $\begin{array}{l}\text { Decision based on Results (no } \\
\text { mitgiation) }\end{array}$ & & $\begin{array}{l}\text { Based on USEPA threshold levels } \\
\text { the concentration of } \\
\text { contamination on-site is well } \\
\text { below exposure levels. }\end{array}$ & $\begin{array}{l}\text { The very low levels of } \\
\text { contamination on-site do not } \\
\text { transport off-site and are therefore } \\
\text { very unlikely to lead to negative } \\
\text { public perception. }\end{array}$ & $\begin{array}{l}\text { No remediation is required on-site } \\
\text { for the very low concentration } \\
\text { levels. }\end{array}$ \\
\hline 4 & Mititgation measures & $\begin{array}{l}\text { Implement a monitoring regime to } \\
\text { ensure land contamination } \\
\text { continues to be a low risk. }\end{array}$ & $\begin{array}{l}\text { Undertake regular soil sampling to } \\
\text { ensure levels remain below } \\
\text { threshold. }\end{array}$ & $\begin{array}{l}\text { Continue to monitor } \\
\text { contamination and local } \\
\text { environment. }\end{array}$ & $\begin{array}{l}\text { Regular monitoring will ensure } \\
\text { any requirement for remediation is } \\
\text { identified early, therefore } \\
\text { minimizing cost. }\end{array}$ \\
\hline
\end{tabular}


74 To further support sampling results, controlled laboratory soil columns using local soil and climate conditions, and representative concentrations of explosives demonstrated that the residues remained in the top layer of soil for long periods and proved unlikely to be transported off-site in significant concentrations.

Stage 3 assisted the manufacturer to decide that remediation was not required as there was minimal risk to the environment or the business. As contamination levels on-site were well below US EPA exposure limits, the compliance risk was deemed very low. In addition, the sampling showed that no contamination had been transported off-site and therefore the risk to reputation was also very low. Finally, the low levels of contamination found during sampling indicated no remediation was required at this time. Therefore, in each of the business risk columns of the Decision Framework the manufacturer decided that the open-burning activity could continue, and scored all business risks 'green'.

If the Decision Framework had not been used to complement the initial environmental impact assessment, the manufacturer may have assumed that the environmental risk from openburning was much higher than it was actually found to be. This may have resulted in unnecessary action such as costly remediation or mitigation and the cessation of open-burning on-site in response to pressure from stakeholder perceptions. The alternative of transporting explosive waste off-site for disposal could have had raised safety issues and increased costs.

Therefore, the Decision Framework enabled the manufacturer to make a proportional decision in response to credible scientific data, which could also be used to appease stakeholder concerns.

\subsection{Case Study 3: Air pollution from open burning of explosives}

As mentioned in Section 3.2 open-burning has been used for the safe disposal of explosives, although it often receives negative public perception due to the volume of unsightly and 
odorous black smoke. Perception of this activity does not always align with the actual environmental impact, which may be minimal compared to the alternative e.g. long-distance transport off-site and energy intensive demilitarisation (49). In this case, the manufacturer was

101 keen to follow good environmental practice by understanding any adverse environmental 102 impact from their open-burning activities, being compliant with legislation and anticipating 103 any stakeholder complaints. Therefore, the manufacturer used the Decision Framework to decide whether to continue open-burning or investigate alternative options.

The manufacturer conducted daily open-burning of explosives and explosive waste such as personal protective equipment and packaging. Following the manufacturer's environmental risk assessment, the Decision Framework was applied to assess whether the concentration of toxins during open-burning had an adverse environmental impact. The potential environmental impacts identified from the site environmental risk assessment were localised air pollution from toxic emissions, contribution to climate change from generation of greenhouse gasses, nuisance

111 and odour from black smoke. In Stage 1 the key business risks were negative perception as the 112 company had already received complaints about the black smoke from the burning, and the 113 potential toxicity to local residents. Intense public interest could lead to nuisance investigations

114 by local authorities and potentially legal actions and fines if the activity was found to 115 contravene legislation or cause contamination (Figure 5). Directed questions generated in 116 Stage 2 of the Decision Framework focused on the composition and concentration of gaseous 117 products emitted during open-burning, and whether legislative threshold limits were being exceeded (Figure 5).

119 There are several scientific approaches for characterizing air emissions from open-burning of 120 explosives $(45,50,51)$. As there is limited guidance on environmental exposure limits from 121 open-burning, occupational health guidelines are often applied. In this case, the concentration of toxic and greenhouse gasses emitted from the daily open burning was quantified by using 
123 an in-situ continuous monitoring system for carbon monoxide, carbon dioxide and nitrous

124 oxide for the duration of the burn. In addition, activated carbon adsorption was used to capture

125 other suspected toxic gasses. Results were compared to suggested burning decomposition

126 products as cited in the literature. Due to the very small quantities of explosive included

127 amongst the explosive contaminated waste during the daily burning, the emissions were as

128 expected for general packing waste and not significantly altered by the presence of explosive

129 i.e. no toxic explosive decomposition products were identified. However, during the

130 continuous monitoring it was noticed that significant volumes of black smoke were generated

131 most likely from the hard plastics being burned e.g. personal protective equipment.

132 Even though greenhouse gasses are emitted during open burning they are low in concentration compared to industrial activity and are rapidly dispersed in air. Therefore, the greenhouse gas

134 emissions are unlikely to have a significant adverse impact on the environment, however the

135 approach was not able to capture all potential toxins such as dioxins released from open-

136 burning of plastics and therefore the manufacturer decided that further work was required to

137 make a decision on environmental impact. Based on the review of legislation the manufacturer

138 decided that the risk to compliance was low as there are no legal environmental restrictions on

139 open-burning of explosives and the activity could continue by assigning a 'green' score.

140 However, the Decision Framework process highlighted that the risk to reputation remained

141 high due to the generation of black smoke and the continuing unknowns surrounding the

142 generation of other toxic contaminants, which the manufacturer decided was too significant to 143 ignore and therefore scored 'red'. 
Table 4: Completed Decision Framework for case study 3. Due to the high reputational risk and the unknown quantities of toxins produced from open-burning as a result of

145 the application of the Decision Framework the manufacturer decided to re-assess the requirement for open-burning on the site in favour of disposal off-site or the use of a

146 specialist incinerator on-site.

\section{Potentially high impact activity: Open burning of explosives and explosive contaminated waste}

\begin{tabular}{|c|c|c|c|c|c|}
\hline \multirow{2}{*}{\multicolumn{2}{|c|}{ Stage }} & \multirow{3}{*}{\begin{tabular}{l}
\multicolumn{1}{|c|}{$\begin{array}{c}\text { Potential Environmental } \\
\text { Impact }\end{array}$} \\
Potential air pollution from \\
generation of toxic emissions and \\
particulates. Contribution to \\
climate change from generation of \\
greenhouse gasses. Nuisance \\
from odour and smoke. Potential \\
land contamination from \\
particulates and explosive \\
residue.
\end{tabular}} & \multicolumn{3}{|c|}{ Business Risks } \\
\hline & & & \multirow[b]{2}{*}{$\begin{array}{l}\text { Compliance } \\
\\
\text { Potential requirement for licence } \\
\text { for emission of gasses from open } \\
\text { burning. Potential threshold limits } \\
\text { for gasses. }\end{array}$} & \multirow[b]{2}{*}{\begin{tabular}{|l} 
Reputation \\
\\
Negative public perception of \\
black smoke and potential \\
toxicity leading to negative \\
reputation, local authority \\
attention and potential loss of \\
business. Potential for legal \\
action by public due to nuisance.
\end{tabular}} & \multirow[b]{2}{*}{$\begin{array}{l}\text { Finance } \\
\\
\text { Potential fines for non-compliance } \\
\text { and breaching threshold levels. } \\
\text { Costs associated with legal } \\
\text { proceedings. }\end{array}$} \\
\hline 1 & $\begin{array}{l}\text { Operational risks arising from } \\
\text { potential adverse environmental } \\
\text { impact }\end{array}$ & & & & \\
\hline 2 & $\begin{array}{l}\text { Questions arising from risk } \\
\text { assessment }\end{array}$ & $\begin{array}{l}\text { What gasses are emitted during } \\
\text { open burning? Do the emitted } \\
\text { concentrations present a risk? }\end{array}$ & $\begin{array}{l}\text { Is a licence required for open } \\
\text { burning? Are there any threshold } \\
\text { limits? }\end{array}$ & $\begin{array}{l}\text { Do the emitted concentrations of } \\
\text { gas present a risk to the public? } \\
\text { Can the generation of black } \\
\text { smoke be minimized? }\end{array}$ & $\begin{array}{l}\text { How likely is non-compliance with } \\
\text { threshold limits during open } \\
\text { burning? }\end{array}$ \\
\hline \multicolumn{6}{|c|}{ Scientific investigation undertaken: Continuous air monitoring, literature search } \\
\hline \multirow[b]{2}{*}{3} & Continue process? & \multirow[b]{2}{*}{$\begin{array}{l}\text { Greenhouse gasses are emitted } \\
\text { during open burning, but } \\
\text { concentration levels decline } \\
\text { before smoke is transmitted off- } \\
\text { site due to dilution in air. } \\
\text { However, not all potential gaseous } \\
\text { emissions were captured and } \\
\text { therefore a question remains } \\
\text { surrounding impact. }\end{array}$} & $\mathbf{Y}$ & $\mathbf{N}$ & $\mathbf{Y}$ \\
\hline & Decision based on Results & & $\begin{array}{l}\text { Licences and legislation do not } \\
\text { cover open-burning of explosives, } \\
\text { therefore threshold limits do not } \\
\text { apply. }\end{array}$ & $\begin{array}{l}\text { The emitted concentrations of } \\
\text { gasses do not present a risk to } \\
\text { the public as they are quickly } \\
\text { diluted. However, black smoke is } \\
\text { likely to cause negative public } \\
\text { perception. }\end{array}$ & $\begin{array}{l}\text { No threshold limts therefore } \\
\text { unlikely to be non-compliant. }\end{array}$ \\
\hline \multirow[t]{2}{*}{4} & Mitigation measures Option 1 & $\begin{array}{l}\text { Consider current open-burning } \\
\text { practices to see if improvement is } \\
\text { possible to reduce negative public } \\
\text { perception. }\end{array}$ & & $\begin{array}{l}\text { Consider composition of waste to } \\
\text { reduce black smoke generation } \\
\text { e.g. avoid burning heavy plastic, } \\
\text { wash and dispose instead. }\end{array}$ & \\
\hline & Mititgation measures Option 2 & \begin{tabular}{|l|} 
For best practice, consider \\
controlling disposal processes by \\
using incinerator with filters.
\end{tabular} & $\begin{array}{l}\text { If using incinerator licenses will } \\
\text { apply, and emission permits can } \\
\text { be obtained. }\end{array}$ & $\begin{array}{l}\text { Incinerator would significantly } \\
\text { reduce black smoke. }\end{array}$ & $\begin{array}{l}\text { Monitor emissions to ensure } \\
\text { permit requirements are met. }\end{array}$ \\
\hline
\end{tabular}


148 Therefore, two mitigation measures were suggested to reduce negative public perception: 1) a

149 review of waste management practices to avoid burning heavy plastics, responsible for the

150 generation of black smoke and potential toxins, and 2) using an alternative on-site disposal

151 method, such as incineration. Having observed this issue the manufacturer was able to

152 immediately implement a change to the waste management process to ensure that materials

153 that could be decontaminated by thorough washing with solvent e.g. plastic personal

154 protective equipment were not disposed of by open-burning. In the long term, the

155 manufacturer plans to investigate alternative methods of disposal with the intention of

156 eliminating the practice of open-burning.

157 If the Decision Framework had not been used to complement the initial environmental impact assessment air emissions monitoring may not have been carried out as there are no environmental restrictions on open-burning of explosives. However, the inclusion of

160 reputational and stakeholder concerns in the Decision Framework enabled the manufacturer

161 to apply discretionary principles to achieve environmental best practice beyond statutory

162 requirements.

\section{$163 \quad 3.4$ Conclusion}

164 Three case studies have been used to demonstrate how the Decision Framework can assist manufacturers in making simple binary decisions on whether to proceed with an existing

166 process by generating directed questions for further quantitative research. The examples used

167 in this paper illustrated how linking environmental impacts to business risks can assist

168 manufacturers to assess a wide spectrum of issues that might not be identified in the initial 169 environmental assessment. Specifically, case study 1 highlighted the importance of 170 determining a permissible concentration of the new explosive in the discharged water that 171 would ensure no discolouration. Further to this, inclusion of both the compliance and 172 reputational risk aspects in the Decision Framework demonstrated that there was a significant 
173 risk and that mitigation would be required. A traditional approach based on eco-toxicity 174 assessment would not have highlighted this issue. Case study 2 demonstrated how the Decision

175 Framework enabled the manufacturer to evidence their decision not to remediate and continue 176 open-burning, as the practice was not causing significant contamination. Case study 3 further 177 illustrates how the Decision Framework assisted the manufacturer to go beyond statutory 178 requirements and consider stakeholder perception as a significant risk.

179 The Decision Framework is only beneficial where a manufacturer has already completed, or 180 plans to complete, an initial environmental assessment as it supports in-depth investigation into 181 a particular issue. In addition, it requires the manufacturer to take responsibility for making 182 decisions, specifically whether the activity should go ahead by assigning a 'green' colour if 'yes' i.e. the activity can continue, or a 'red' colour if 'no' i.e. the activity should stop until an alternative can be found. The Decision Framework was developed with an intentionally narrow focus on specific operational activities that have potentially significant environmental impacts and therefore complements other environmental assessment and management processes rather than replacing them. This was particularly important, as initial assessments are usually subjective, and do not have access to detailed scientific data, but are excellent tools to highlight where there are unknowns, or where there are potentially significant environmental impacts. The Decision Framework can then be used to support in depth investigation into particular

191 activities of interest. Although the Decision Framework was developed for explosive 192 manufacturers, it could be used at other stages in the munition lifecyle, or in other industries, and in addition can modified to suit the needs of a particular company. For example, the three exemplar business risk categories could be replaced or augmented with more relevant categories such as health and safety, ethical risk or strategic risk. Alternatively, a sustainability approach may be adopted with environmental, social and economic categories. Finally, though environmental assessment is often a legal requirement, environmental management is not 
mandated and therefore may be difficult to justify. It is hoped that the Decision Framework may provide a tool to aid explosive manufacturers justify environmental best practice, not only to reduce environmental impact, but also to promote sustainable operations.

\section{Acknowledgements}

202 This work is supported by Cranfield University and EPSRC Industrial Case Award. We

203 would also like to thank Dr R. Twyman for reviewing the manuscript and C. Pratchett at

204 Cranfield University for developing the graphical abstract.

\section{References}

206 1. C. Ferreira, F. Freire, J. Ribeiro, in Energetic materials and munitions : life cycle management, environmental impact, and demilitarization, A. S. Cumming, M. S. Johnson, Eds. (Wiley-VCH Verlag GmbH, Weinheim, ed. 1, 2019, ISBN:9783527816644), pp. 169-195.

2. The Contaminated Land (England) Regulations 2006 (available at http://www.legislation.gov.uk/uksi/2006/1380/contents/made).

3. Water Resources Act 1991 (Statute Law Database, 1991; https://www.legislation.gov.uk/ukpga/1991/57).

214 4. The Environmental Permitting Regulations 2010. SI 675 (England and Wales, 2010; http://www.legislation.gov.uk/uksi/2010/675/contents/made).

216 5. ISO - International Organization for Standardization, ISO 14040 International Standard. Environmental management - Life cycle assessment - Principles and framework (International Organisation for Standardization, Geneva, Switzerland., 2006).

6. The International Standards Organisation, Environmental management - Life cycle 
assessment — Principles and framework. Iso 14040. 2006, 1-28 (2006).

222

7. C. Ferreira, J. Ribeiro, S. Almada, F. Freire, Environmental Assessment of Ammunition: the Importance of a Life-Cycle Approach. Propellants, Explos. Pyrotech. 42, 44-53 (2017).

8. E. Galante, T. Temple, M. Ladyman, P. P. Gill, The UK Ministry of Defence Project Orientated Environmental Management System (POEMS). Propellants, Explos. Pyrotech. 42, 36-43 (2017).

9. L. A. Cox, What's Wrong with Risk Matrices? Risk Anal. 28, 497-512 (2008).

10. R. K. Morgan, Impact Assessment and Project Appraisal Environmental impact assessment: the state of the art Environmental impact assessment: the state of the art (2012), doi:10.1080/14615517.2012.661557.

11. L. Ortolano, A. Shepherd, Environmental Impact Assessment: Challenges and Opportunities. Impact Assess. 13, 3-30 (1995).

12. C. C. Murray et al., The Insignificance of Thresholds in Environmental Impact Assessment: An Illustrative Case Study in Canada. Environ. Manage. 61, 1062-1071 (2018).

13. T. Põder, Evaluation of Environmental Aspects Significance in ISO 14001. Environ. Manage. 37, 732-743 (2006).

14. E. Perotto, R. Canziani, R. Marchesi, P. Butelli, Environmental performance, indicators and measurement uncertainty in EMS context: a case study. J. Clean. Prod. 16, 517-530 (2008).

15. J. Beyer et al., Environmental risk assessment of combined effects in aquatic ecotoxicology: A discussion paper. Mar. Environ. Res. 96, 81-91 (2014). 
16. A. D. Hewitt, T. F. Jenkins, M. E. Walsh, M. R. Walsh, S. Taylor, RDX and TNT residues from live-fire and blow-in-place detonations. Chemosphere. 61, 888-894 (2005).

17. J. C. Pennington, B. Silverblatt, K. Poe, C. A. Hayes, S. Yost, Explosive Residues from Low-Order Detonations of Heavy Artillery and Mortar Rounds. Soil Sediment

18. D. J. Freeman, O. A. Colitti, "Removal of Explosives from Load-Assemble-Pack wastewater (pink water) using surfactant technology” (Dover, New Jersey, 1982), (available at http://www.dtic.mil/dtic/tr/fulltext/u2/a115086.pdf).

19. E. Kitcher, W. Braida, A. Koutsospyros, J. Pavlov, T. L. Su, Characteristics and products of the reductive degradation of 3-nitro-1,2,4-triazol-5-one (NTO) and 2,4dinitroanisole (DNAN) in a Fe-Cu bimetal system. Environ. Sci. Pollut. Res. 24, 27442753 (2017).

20. J. Clausen, J. Robb, D. Curry, N. Korte, A case study of contaminants on military ranges: Camp Edwards, Massachusetts, USA. Environ. Pollut. 129, 13-21 (2004).

21. C. Rajagopal, J. . Kapoor, Development of adsorptive removal process for treatment of explosives contaminated wastewater using activated carbon. J. Hazard. Mater. 87, 7398 (2001).

22. D. Felt et al., "Technical Report: Evaluation of Treatment Technologies for Wastewater from Insensitive Munitions Production; Phase 1: Technology DownSelection (ERDC/EL TR-13-20)" (Vicksburg, 2013).

23. G. R. Lotufo, A. B. Gibson, J. Leslie Yoo, Toxicity and bioconcentration evaluation of RDX and HMX using sheepshead minnows in water exposures. Ecotoxicol. Environ. 
Saf. 73, 1653-1657 (2010).

268

24. M. S. Johnson, G. Reddy, Wildlife toxicity assessments for chemicals of military concern (Elsevier, ed. 1st, 2015, ISBN:9780128000205).

25. T. A. Anderson, in Wildlife Toxicology: Emerging Contaminant and Biodiversity Issues (CRC Press., 2010), pp. 15-38.

26. G. R. Lotufo, G. Rosen, W. Wild, G. Carton, "Summary review of the aquatic toxicology of munitions constituents" (Hanover, 2013).

27. United States Environmental Protection Agency, "Technical Fact Sheet - 2,4,6Trinitrotoluene (TNT)" (2014), (available at https://www.epa.gov/sites/production/files/201403/documents/ffrrofactsheet_contaminant_tnt_january2014_final.pdf).

28. United States Environmental Protection Agency, “Technical Fact Sheet - Hexahydro1,3,5-trinitro-1,3,5-triazine (RDX)" (2014), (available at https://www.epa.gov/sites/production/files/201403/documents/ffrrofactsheet_contaminant_rdx_january2014_final.pdf).

29. A. Finizio, S. Villa, Environmental risk assessment for pesticides: A tool for decision making. Environ. Impact Assess. Rev. 22, 235-248 (2002).

30. J. A. Hagger et al., "Biomarkers and Integrated Environmental Risk Assessment: Are There More Questions Than Answers?," (available at https://setac.onlinelibrary.wiley.com/doi/pdf/10.1002/ieam.5630020403).

31. Environmental Protection Act 1990: Section 79. (Parliament of the United Kingdom, London, 1990; https://www.legislation.gov.uk/ukpga/1990/43/pdfs/ukpga_19900043_en.pdf), vol. 
1990.

291 32. K. Alverbro, A. Björklund, G. Finnveden, E. Hochschorner, J. Hägvall, A life cycle assessment of destruction of ammunition. J. Hazard. Mater. 170, 1101-1109 (2009).

33. J. Toro, I. Requena, O. Duarte, M. Zamorano, A qualitative method proposal to improve environmental impact assessment. Environ. Impact Assess. Rev. 43, 9-20 (2013).

34. The Commission of the European Communities, "Commission Recommendation on guidance for the implementation of Regulation (EC) No 761/2001 of the European Parliament and of the Council allowing voluntary participation by organisations in a Community ecomanagement and audit scheme (EMAS)" (2001), (available at https://eur-lex.europa.eu/legalcontent/EN/TXT/PDF/?uri=CELEX:32001H0680\&from=EN).

35. K. Steele, The precautionary principle: a new approach to public decision-making? Law, Probab. Risk. 5, 19-31 (2006).

36. D. McCaughey, N. S. Bruning, Rationality versus reality: the challenges of evidencebased decision making for health policy makers. Implement. Sci. 5, 39 (2010).

37. BSI Standards Publication, "Environmental management systems-General guidelines on implementation" (2016), (available at https://extranet.cranfield.ac.uk/Download/,DanaInfo=bsol.bsigroup.com,SSL+Subscrip tionPdfDocument?materialNumber $=000000000030263814 \&$ documentNumber $=\mathrm{BS}$ EN ISO 14004\%3A2016).

311 38. R. Hillary, K. Loth, Environmental review of general practice: implications for new primary healthcare groups. Eco-Management Audit. 5, 95-100 (1998). 
313 39. D. Marazza, V. Bandini, A. Contin, Ranking environmental aspects in environmental management systems: A new method tested on local authorities. Environ. Int. 36, 168179 (2010).

40. A. Johnston, J. Hutchison, A. Smith, Significant environmental impact evaluation: a proposed methodology. Eco-Management Audit. 7, 186-195 (2000).

41. T. Zobel, J.-O. Burman, Factors of importance in identification and assessment of environmental aspects in an EMS context: experiences in Swedish organizations. $J$. Clean. Prod. 12, 13-27 (2004).

42. Y. Liu, H. Gupta, E. Springer, T. Wagener, Linking science with environmental decision making: Experiences from an integrated modeling approach to supporting sustainable water resources management. Environ. Model. Softw. 23, 846-858 (2008).

43. B. Ness, E. Urbel-Piirsalu, S. Anderberg, L. Olsson, Categorising tools for sustainability assessment. Ecol. Econ. 60, 498-508 (2007).

44. Health and Safety Executive, Explosives Regulations 2014: Safety provisions (HSE Books, 2014, ISBN:9780717665518; www.nationalarchives.gov.uk/doc/opengovernment-licence/,).

45. R. W. Gerstle, D. A. Kemnitz, Atmospheric emissions from open burning. J. Air Pollut. Control Assoc. (1967), doi:10.1080/00022470.1967.10468988.

46. J. L. Clausen, $\cdot$ T Georgian, $\cdot \mathrm{K}$ H Gardner, $\cdot$ T A Douglas, Applying Incremental Sampling Methodology to Soils Containing Heterogeneously Distributed Metallic Residues to Improve Risk Analysis. Bull. Environ. Contam. Toxicol. 100, 155-161

47. US Environmental Protection Agency, "EPA Method 8330B (SW-846): 
Nitroaromatics and Nitramines by High Performance Liquid Chromatography (HPLC)” (2006), (available at https://www.epa.gov/sites/production/files/201507/documents/epa-8330b.pdf).

48. M. E. Walsh, T. F. Jenkins, P. S. Schnitker, J. W. Elwell, M. H. Stutz, "Evaluation of SW846 Method 8330B for Characterization of Sites Contaminated with Residues of High Explosives" (Hanover, 1993), (available at http://www.dtic.mil/dtic/tr/fulltext/u2/a268700.pdf).

49. N. J. Duijm, F. Markert, Assessment of technologies for disposing explosive waste. $J$. Hazard. Mater. 90, 137-153 (2002).

50. P. M. Lemieux, C. C. Lutes, D. A. Santoianni, Emissions of organic air toxics from open burning: a comprehensive review. Prog. Energy Combust. Sci. 30, 1-32 (2004).

347 51. J. Aurell, B. K. Gullett, C. Pressley, D. G. Tabor, R. D. Gribble, Aerostat-lofted instrument and sampling method for determination of emissions from open area sources. Chemosphere. 85, 806-811 (2011). 